\title{
The Alberta LiQUOR CONTROL BOARD AND THE QUESTION OF ADMINISTRATIVE INDEPENDENCE, 1924-1939
}

\author{
SARAH E. HAMILL ${ }^{*}$
}

\begin{abstract}
This article discusses administrative independence by using Alberta's first attempt at creating a Liquor Control Board as a case study. The article examines the relationships between the Board, the government, and the public in order to contribute to a more rigorous understanding of administrative independence that goes beyond the usual comparisons to judicial independence.
\end{abstract}

\section{TABLE OF CONTENTS}

I. INTRODUCTION ................................. 747

II. THE QUESTION OF ADMINISTRATIVE INDEPENDENCE . . . . . . . . . . . . 749

III. CREATING THE ALCB: CASH, COMPLEXITY, AND CONTROVERSY . . . . 756

IV. THE LIQUOR CONTROL ACT AND THE ALCB . . . . . . . . . . . . 760

V. CAUTION, OVERSIGHT, AND THE LiQUOR BuSINESS:

THE ALCB's RELATIONSHIP WITH THE GOVERNMENT . . . . . . . . . 762

VI. THE ALCB'S RELATIONAL INDEPENDENCE:

SOME BROADER IMPLICATIONS $\ldots \ldots \ldots \ldots \ldots \ldots \ldots \ldots \ldots \ldots \ldots \ldots$

VII. CONCLUSION .............................. 774

\section{INTRODUCTION}

In 1924 the Alberta government finally answered the demands of the Prohibitionists and created an independent board to administer the province's liquor laws. ${ }^{1}$ The Prohibitionists had been calling for such a body since $1916,{ }^{2}$ yet the creation of the Alberta Liquor Control Board (ALCB) in 1924 was marred by the fact that it was simultaneous with the end of prohibition. Although the question of what kind of body should administer Alberta's liquor laws was never central to the liquor issue in that province, the creation of the ALCB can shed some light on the long-standing puzzle of administrative independence. Why was it that Prohibitionists demanded an independent body and was the ALCB actually as independent as it seemed to be?

The ALCB emerged at a time when similar administrative agencies were cropping up across Canada. The rise of the administrative state posed some problems for those trained in the common law and many early administrative agencies faced both a hostile judiciary and

Catalyst Fellow, 2015-16, Osgoode Hall Law School. This article is based on a chapter of my doctoral dissertation, Sarah Hamill, From Prohibition to Administrative Regulation: The Battle for Liquor Control in Alberta, 1916 to 1939, (PhD Dissertation, University of Alberta, Faculty of Law, 2014) [unpublished]. For helpful comments on earlier drafts I would like to thank Eric Adams, Doug Harris, John Law, Matthew Lewans, James Muir, Frances Swyripa, and three anonymous peer reviewers. Government Liquor Control Act of Alberta, SA 1924 (4th Sess), c 14, s 4 [Liquor Control Act].

"\$80,000 in Estimates to put Prohibition Act into Force," Edmonton Bulletin (30 March 1916) 1 ["Estimates"] (noting the pre-coming into force discussions around how best to administer prohibition). 
legal academy. ${ }^{3}$ While both scholars and judges are now significantly less opposed to the administrative state, the exact nature of administrative agencies remains both under-explored and under-theorized. ${ }^{4}$ Given that administrative agencies like the ALCB developed on an ad hoc basis, the rise of the administrative state was not part of a planned process; it emerged piecemeal and many early boards were short-lived. ${ }^{5}$ This suggests that such bodies were experimental responses to specific problems. The relatively improvised nature of the administrative state may go some way in explaining why administrative agencies are still an awkward legal, constitutional, and political fit in common law countries such as Canada ${ }^{6}$ but as they are (almost certainly) here to stay, it is perhaps time to have a better understanding of them.

While this article cannot possibly sketch out a complete picture of the administrative state, it does start to develop some answers to the question of what administrative independence actually looks like. The exact nature of administrative independence has received some academic attention but much of the discussion fails to actually examine the administrative bodies themselves. ${ }^{7}$ Existing studies focus almost exclusively on the adjudicative functions of administrative bodies or on what might be termed "administrative justice." As a result, administrative independence seems to mean that administrators are free from political influence and, as such, is often compared with judicial independence. ${ }^{8}$ Yet few scholars have actually examined an administrative body's relationship with the government to see if it really is independent in the same sense as the judiciary, or whether that model of independence is even desirable for administrators. Certainly in the context of mainly

3 See generally The Right Honourable Lord Hewart of Bury, The New Despotism (London, UK: Ernest Benn Limited, 1929). See also R Blake Brown, "The Canadian Legal Realists and Administrative Law Scholarship, 1930-1941” (2000) 9 Dal J Leg Stud 36.

This is a longstanding problem: see e.g. John Willis, "Foreword" in John Willis, ed, Canadian Boards at Work (Toronto: MacMillan, 1941), v [Willis, "Foreword"]; John Willis, "Canadian Administrative Law in Retrospect" (1974) 24:2 UTLJ 225 at 228 [Willis, "Canadian Administrative Law"]. There are, of course, some exceptions see e.g. Laverne Jacobs, "A Wavering Commitment? Administrative Independence and Collaborative Governance in Ontario's Adjudicative Tribunals Accountability Legislation" (2010) 28:2 Windsor YB Access Just 285 [Jacobs, “A Wavering Commitment”]; Lorne Sossin, "The Rule of Policy: Baker and the Impact of Judicial Review on Administrative Discretion" in David Dyzenhaus, ed, The Unity of Public Law (Oxford: Hart, 2004) 87 [Sossin, "Rule of Policy"]; Philip Bryden \& Ron Hatch, "British Columbia Council of Administrative Tribunals Research and Policy Committee - Report on Independence, Accountability and Appointment Processes in British Columbia Tribunals" (1998) 12 Can J Admin L \& Prac 235; Pierre Noreau et al, La Justice Administrative: Entre Indépendence et Responsiblité (Cowansville: Éditions Yvon Blais, 2014). For an English translation of the summary of findings see, France Houle et al, "Administrative Justice: Independence and Responsibility — Towards a Common Regime for Independent Adjudicators" (2014) 27 Can J Admin L \& Prac 219; Ron Ellis, Unjust by Design: Canada's Administrative Justice System (Vancouver: UBC Press, 2013) [Ellis, Unjust by Design].

5 Bernard J Hibbitts, "A Change of Mind: The Supreme Court and the Board of Railway Commissioners, 1903-1929" (1991) 41:1 UTLJ 60; Bernard J Hibbitts, “A Bridle for Leviathan: The Supreme Court and the Board of Commerce" (1989) 21:1 Ottawa L Rev 65 [Hibbitts, "Bridle for Leviathan"]; Jamie Benidickson, "The Canadian Board of Railway Commissioners: Regulation, Policy and Legal Process at the Turn-of-the-Century" (1991) 36:4 McGill LJ 1222; Willis, "Foreword," supra note 4 at vi.

6 This is a long-standing problem: see John Willis, "Three Approaches to Administrative Law: The Judicial, the Conceptual, and the Functional" (1935) 1:1 UTLJ 53 at 59. For modern comments, see Lorne Sossin, "The Puzzle of Independence for Administrative Bodies" (2009) 26:1 NJCL 1 at 2 [Sossin, "Puzzle"]; Matthew Lewans, "Rethinking the Diceyan Dialectic" (2008) 58:1 UTLJ 75 at 75-76. See also HN Janisch, "Policy Making in Regulation: Towards a New Definition of the Status of Independent Regulatory Agencies in Canada" (1979) 17:1 Osgoode Hall LJ 46 at 64 [Janisch, "Policy Making"] for discussion of some of the issues of a piecemeal development.

See e.g. Sossin, "Puzzle," ibid; Lorne Sossin, "Speaking Truth to Power? The Search for Bureaucratic Independence in Canada" (2005) 55:1 UTLJ 1 [Sossin, "Speaking Truth"]. For some exceptions, see Sossin, "Rule of Policy," supra note 4; Jacobs, supra note 4; Ellis, Unjust by Design, supra note 4; Noreau et al, supra note 4. See e.g. Sossin, "Puzzle," ibid at 5-7. 
adjudicative bodies, the model of judicial independence seems both preferable and readily applicable, but many administrative bodies have more than just an adjudicative function. How might these competing functions interact and what do they mean for administrative independence?

In this article I perform a microanalysis ${ }^{9}$ of the ALCB in order to explore the Board's relationship with the government and what its independence meant. This microanalysis relies on a variety of sources including archival sources, such as interdepartmental memos and correspondence, the ALCB's own records, and newspaper articles, as well as the more traditional legal sources of case law, legislation, and academic commentary. My focus is limited to the Board's first 15 years for two main reasons. The first is that by the end of the 1930 s virtually every other Canadian province had ended prohibition, meaning that the ALCB and liquor sales no longer seemed like an experiment and had become normalized. The second is that the Second World War prompted a number of changes, including increased normalization of liquor consumption, ${ }^{10}$ and in the operation of government. Through this microanalysis, I argue that the ALCB, particularly in its early years, was not independent in the same sense as the judiciary; rather, the independence of the ALCB was highly relational and interdependent on both the relationships that the ALCB had with other parts of the government, the public, and on the ALCB's own perception of those relationships. In making this argument I rely on Jennifer Nedelsky's work on relational autonomy, which emphasizes the importance of relationships to an individual's ability to be autonomous, but I apply Nedelsky's arguments to institutions rather than individual citizens. ${ }^{11}$ The ALCB was accountable to the government and the public in a range of ways which were not fully captured by the legislation which created the Board. Yet the ALCB was also more than accountable, it was responsive to the demands of the public and the government and this responsiveness was motivated by a range of factors including the ALCB's precarious position in its early years.

I begin with a discussion of what administrative law scholars have had to say about administrative independence. I then move on to explain why Alberta created the ALCB in 1924. Most other, if not all Canadian provinces, already had such an independent body throughout or even predating prohibition. Alberta's delay in creating a separate liquor board offers some insight into the competing arguments surrounding such bodies; arguments which were equal parts political and practical. Part IV explores what the Liquor Control Act had to say about the ALCB, while Part V explores how the ALCB actually operated in practice. Part VI unpacks some of the broader implications of this article. Part VII concludes.

\section{THE QUESTION OF ADMINISTRATIVE INDEPENDENCE}

When administrative law scholars speak of administrative bodies they often note that it is hard to account for such bodies in the current theoretical landscape because they do not of Discourse, and the Microanalysis of Institutions" (1996) 109:6 Harv Law Rev 1393.

Craig Heron, Booze: A Distilled History (Toronto: Between the Lines, 2003) at 313-14.

Jennifer Nedelsky, Law's Relations: A Relational Theory of Self, Autonomy, and Law (Oxford: Oxford University Press, 2011) at 3. 
seem to fit with the separation of powers. ${ }^{12}$ Many administrative bodies have judicial, legislative, and administrative functions but the exact breakdown of these functions vary; some bodies are almost entirely concerned with adjudication while others are almost entirely regulatory. Then there is the question of how to balance the need for accountability and responsibility with the need for independence on the part of those who determine the "rights or interests of others on the basis of law."13 Where academics have investigated the concept of administrative independence they have usually done so in the context of boards which have a mainly judicial function. ${ }^{14}$ Not surprisingly, judicial independence offers the obvious comparator. Yet when the Alberta government created the ALCB in 1924, the independence that it and observers had in mind was not necessarily related to the particular governmental functions of the Board, it was related to the controversy surrounding liquor sales. This section sets out the various meanings of administrative independence by unpacking what administrative bodies do and why they were created.

As noted, many early administrative bodies were short-lived and faced a deeply hostile judiciary and legal profession. Starting in the 1930s and into the 1940s a group of Canadian legal scholars, sometimes called the "Canadian legal realists," began to defend administrative government. ${ }^{15}$ John Willis was the most famous of these scholars and his work often skewered those who would critique administrative bodies, mocking the critics' lofty concern with eighteenth century ideals instead of studying the boards themselves. ${ }^{16}$ Willis adopted a practical approach to understanding the administrative state, noting that its development was essential to the work of modern government. ${ }^{17}$ One of his key justifications of administrative government was that it was government by experts. ${ }^{18}$ What Willis failed to account for is that expertise is not neutral and is in fact heavily contested. In the example of provincial liquor boards, experts could be temperance activists, policemen, liquor manufacturers, or hotel owners, depending on a person's view of the liquor question. As Janisch put it in the late 1980 s regulation is "an inherently political activity," 19 a point Willis seems to have missed, or at least glossed over. ${ }^{20}$ Certainly administrative law scholars can be too suspicious of administrative actors, seeing them as entirely self-interested, but there is a risk the pendulum could swing too far the other way. ${ }^{21}$ Oversight of administrative bodies remains important; the trick is to strike the right balance between trust and suspicion.

Sossin, "Puzzle," supra note 6 at 7; Lewans, supra note 6 at 75-76, 104; John Willis, "Introduction The Work of an Administrative Board" in Willis, supra note 4, 1 at 2.

Houle et al, supra note 4 at 221.

See generally, Noreau et al, supra note 4; Ellis, Unjust by Design, supra note 4.

RCB Risk, A History of Canadian Legal Thought: Collected Essays (Toronto: University of Toronto Press, 2006) at ch 7, 9, 11; Doug Owram, The Government Generation: Canadian intellectuals and the state, 1900-1945 (Toronto: University of Toronto Press, 1986); Brown, supra note 3.

Willis, "Foreword," supra note 4 at viii.

Ibid at $\mathrm{v}$.

John Willis, "Introduction - Administrative Discretion" in Willis, supra note 4, 65 at 68; Brown, supra note 3 at 50-51, 69; David J Mullan, "Willis v McRuer: A Long-Overdue Replay with the Possibility of a Penalty Shoot-Out" (2005) 55:3 UTLJ 535 at 548, 560. See also JA Corry, "Introduction - The Genesis and Nature of Boards" in Willis, supra note 4, xvii at xxxv.

HN Janisch, "Independence of Administrative Tribunals: In Praise of 'Structural Heretics" "(1988) 1 Can J Admin L \& Prac 1 at 9 [Janisch, "Independence of Administrative"].

Though not everyone in the 1930s did so: see Harold J Laski, "The Limitations of the Expert," Harper's Monthly Magazine 162 (1 December 1930) 101.

See e.g. Jonathan R Macey, "Cynicism and Trust in Politics and Constitutional Theory" (2002) 87:2 Cornell L Rev 280; Cynthia R Farina \& Jeffrey J Rachlinski, "Foreword: Post-Public Choice” (2002) 87:2 Cornell L Rev 267. 
Nonetheless, Willis's other major argument — that scholars should study what actually happens $^{22}$ - remains important if administrative government is to be understood. Few scholars have taken Willis up on his suggestion, which means that there is little information on whether supposedly independent bodies really are independent. Again, what work has been done here, such as Ellis's Unjust by Design, focuses on bodies which are more like courts. This is perhaps not surprising given that legal scholars are more familiar with courts. Yet many administrative agencies often have both adjudicative and policy-making responsibilities, meaning that there is a limit to the applicability of the judicial model as the jurisprudence on administrative independence makes clear. ${ }^{23}$

As such, the first meaning of administrative independence is what might properly be termed "adjudicative independence." I use the term adjudicative independence to both compare it to and distinguish it from judicial independence. The Supreme Court of Canada has held that judicial independence is an unwritten constitutional principle, ${ }^{24}$ which is characterized by security of tenure, secure remuneration, and administrative autonomy. ${ }^{25}$ Independence is thus distinguished from impartiality, with the latter meaning the absence of bias while the former "connotes not merely a state of mind or attitude in the actual exercise of judicial functions, but a status or relationship to others, particularly to the executive branch of government, that rests on objective conditions or guarantees. ${ }^{26}$ While the characteristics of judicial independence inform the jurisprudence on adjudicative independence, the latter is less rigorous. ${ }^{27}$ The Supreme Court has held, for example, that appointing tribunal members for fixed terms is compatible with security of tenure, so long as the tribunal member cannot be removed without cause during his or her term. The judicial acceptance of terms raises the question of reappointment; but, outside of Quebec, the reappointment of tribunal members is something courts are happy to leave to the legislature and they have not required an impartial process. ${ }^{28}$

Furthermore, when it comes to an administrative tribunal's independence, the Court has also held that the three aspects of adjudicative independence are common law rules which can be overturned by a tribunal's enabling legislation. ${ }^{29}$ The exception here is Quebec where section 23 of the Quebec Charter of human rights and freedoms guarantees that "[e]very person has a right to a full and equal, public and fair hearing by an independent and impartial

Willis, "Foreword," supra note 4 at v; Willis, "Canadian Administrative Law," supra note 4 at 228. The Supreme Court of Canada set out the characteristics of judicial independence in Valente v R, [1985] 2 SCR 673 [Valente]. For their application to administrative tribunals, see 2747-3174 Québec Inc v Quebec (Régie des permis d'alcool), [1996] 3 SCR 919 [Régie des permis d'alcool]; Ocean Port Hotel Ltd v British Columbia (General Manager, Liquor Control and Licensing Branch), 2001 SCC 52, [2001] 2 SCR 781 [Ocean Port]; Bell Canada v Canadian Telephone Employees Association, 2003 SCC 36, [2003] 1 SCR 884 [Bell Canada]. For analysis of the jurisprudence, see Lorne M Sossin, "The Ambivalence of Administrative Justice in Canada: Does Canada Need a Fourth Branch?" (2009) 46 $\operatorname{SCLR}(2 \mathrm{~d}) 51$.

Reference re Remuneration of Judges of the Provincial Court of Prince Edward Island; Reference re Independence and Impartiality of Judges of the Provincial Court of Prince Edward Island, [1997] 3 SCR 2 at paras $82-109$

Valente, supra note 23 at 687, 694, 704, 708.

Ibid at 685 .

Bell Canada, supra note 23 at para 21; Association des juges administratifs de le Commission des lésions professionnelles c Québec (Procurer général), 2013 QCCA 1690, [2013] RJQ 1593 at paras 25-26 [CLP]; Noreau et al, supra note 4 at 153.

For discussion of the administrative appointment process, see Ellis, Unjust by Design, supra note 4. For Quebec, see CLP, supra note 27 at paras 51-64.

Ocean Port, supra note 23 at para 20; Philip Bryden, "Structural Independence of Administrative Tribunals in the Wake of Ocean Port" (2002) 16 Can J Admin L \& Prac 125 at 126-27. 
tribunal, for the determination of his rights and obligations or of the merits of any charge brought against him. ${ }^{, 30}$ In applying section 23 to administrative tribunals the Supreme Court uses a contextual approach, where the guarantees of adjudicative independence become stronger the more judicial a board is. ${ }^{31}$ As the Supreme Court noted in Régis des permis d'alcool, "[t]he independence of administrative tribunals, which s. 23 of the [Quebec] Charter protects in addition to impartiality, is based, inter alia, on the relations the decision makers maintain with others and the objective circumstances surrounding those relations." ${ }^{\prime 32}$ As useful as this contextual analysis might be, ${ }^{33}$ there are concerns that it does not offer adequate protection. ${ }^{34}$ Understandably, in the absence of a guarantee like article 23, protections given to adjudicative independence in federal or other provincial administrative bodies are weaker, if they exist at all. Consequently, scholars in both Quebec and elsewhere are calling for the guarantees of judicial independence to be extended to judicial functions, not just bodies which are similar to the courts. ${ }^{35}$

Distinguishing between judicial and administrative functions is not as easy as it sounds; even the Supreme Court of Canada struggles to do so. ${ }^{36}$ Ellis argues that one way to distinguish between the two is to ask whether the law expects a particular function to be performed impartially. He uses the example of an energy board's licencing function as an example of a function which would not be considered judicial. While it is true that an energy board is not bound by the principle of deciding like cases alike, ${ }^{37}$ licencing applicants would expect their applications to be assessed on their merits. The board could not, for example, decline an application because a government minister wanted the licence to go to someone else.

Ellis's primary concern might be those administrative bodies which determine rights inter pares or between the individual and the state, but even energy boards might need some degree of independence in their decision-making. My example of the energy board granting a licence on the basis of a minister's whim is an example of the concern which stalks administrative law scholarship: that agencies and boards will display political partisanship as they make their decisions ${ }^{38}$ or that the administrators will face political reprisals for the decisions they make; and, as a result, they will make their decisions based on personal calculations rather than what is fair. ${ }^{39}$ The leading example of such inappropriate decisionmaking is Roncarelli v. Duplessis, ${ }^{40}$ where the Premier of Quebec intervened in a liquor licencing decision because the licensee in question was a Jehovah's Witness. ${ }^{41}$ Although the majority of the Supreme Court sided with Roncarelli, they reached their decisions by

CQLR, c C-12, s 23 [Quebec Charter] (this section must be read in accordance with, ibid, s 56.) For a development of this principle, see Noreau et al, supra note 4 at 143-85.

Régis des permis d'alcool, supra note 23 at paras $20,45$.

Ibid at para 61 .

For a recent example of how the Quebec Court of Appeal undertakes such an analysis see CLP, supra note 27 at 7.

Noreau et al, supra note 4 at 229; Houle et al, supra note 4 at 229.

Ellis, Unjust by Design, supra note 4; Noreau et al, ibid at 373 (suggesting section 56 of the Quebec Charter, supra note 30 be reworded).

Ellis, Unjust by Design, ibid at 164. This poses additional problems in Quebec: see Noreau et al, ibid at 164-65.

Ellis, Unjust by Design, ibid at 154.

Sossin, "Puzzle," supra note 6 at 4.

Ellis, Unjust by Design, supra note 4.

[1959] SCR 121 [Roncarelli].

Ibid at 133 . 
different routes, the most famous being Justice Rand's decision with its reference to the rule of law. ${ }^{42}$ Following the logic of Justice Rand's decision, Roncarelli should only have lost his licence if he violated some relevant regulation or law, not because his religious beliefs annoyed the government. Roncarelli suggests that independence from politics works to protect the public from the "arbitrary likes, dislikes and irrelevant purposes of public officers acting beyond their duty." ${ }^{43}$ Certainly, there is some consensus that administrative agencies can or should work to shield certain areas from politics, ${ }^{44}$ yet the shielding from politics can cut both ways. It can, for example, work as a way to protect the government from association with certain controversial decisions, as well as working to ensure that administrators make their decisions based on the rule of law, not individuals. ${ }^{45}$

The former function of administrative independence is rarely discussed explicitly, but it is important regardless. Administrative government was not and is not an inevitable development, and the question of why such bodies were created will go some way to explaining the shape that they take. The controversy surrounding the emergence of the administrative state in Canada and the politically sensitive areas in which many early boards worked, suggest that such boards were an answer to the practical necessity, yet political unpopularity, of government intervention in certain areas. ${ }^{46}$ As such, Willis's expert thesis could be understood as part of the depoliticizing of administrative agencies which continues today with modern discussions of administrative independence.

In the common law world, the long-standing suspicion of government and government action against individuals may be answered, at least in part, by the idea of administrative independence. Clearly the notion of independence had and still has some degree of cultural importance; independence is, after all, generally seen as an unqualified good. ${ }^{47}$ It is this cultural aspect of administrative independence which is often overlooked by administrative law scholars. ${ }^{48}$ This idea of independence is usually understood as being freedom from, but as Nedelsky argues, such an understanding does not account for what actually happens and the importance of relationships to ensuring autonomy is achievable. ${ }^{49}$ The jurisprudence on adjudicative independence recognizes the importance of relationships, ${ }^{50}$ but usually looks at the structural guarantees rather than the actual practice..$^{51}$ The courts' concern is more about what the statute says than the operational contexts writ large or what impact a body's operation has on administrative litigants. While such an approach is often disappointing, and

Ibid at 142 .

Ibid.

Sossin, "Puzzle," supra note 6 at 22; Benidickson, supra note 5 at 1223-26; Willis, "Foreword," supra note 4 at vi-vii (Willis noted that this was "an illusion").

There are those who argue that this ideal is impossible: see e.g. Allan C Hutchinson, "The Rule of Law Revisited: Democracy and Courts" in David Dyzenhaus, ed, Recrafting the Rule of Law: The Limits of Legal Order (Oxford: Hart, 1999) 196 at 197.

Willis, "Foreword," supra note 4 at v.

See e.g. Janisch, "Independence of Administrative," supra note 19 at 2.

But see Lewan's argument that certain inheritances, in this case Diceyan theory, can hinder our understanding of the administrative state: Lewans, supra note 6 at 89-97.

Nedelsky, supra note 11 at ch 3.

Régie des permis d'alcool, supra note 23 at para 61.

Laverne A Jacobs, "Tribunal Independence and Impartiality: Rethinking the Theory after Bell and Ocean Port Hotel: A Call for Empirical Analysis" in Laverne A Jacobs \& Anne L Mactavish, eds, Dialogue between Courts and Tribunals: Essays in Administrative Law and Justice 2001-2007 (Montreal: Éditions Thémis, 2008) 43 at 49-50. 
not just in the context of adjudicative independence, legislative intent is one of the pillars of administrative law jurisprudence. ${ }^{52}$

While administrative independence seems to offer administrators some protection against political reprisals, there is a desire to ensure that administrative agencies are accountable, that they are democratic, and that they too obey the rule of law. ${ }^{53}$ Consequently, independent administrative bodies, though apparently free of political influence, are actually subject to the need for political accountability. This is not surprising given that administrative agencies are statutory delegates and so they will be accountable to legislators in some form or other. Yet the need for political accountability does make it harder to argue that such agencies will be completely free from political influence.

In addition to political accountability, administrative agencies are subject to judicial review. Here the development of judicial deference arguably goes some way to protecting administrative independence; or, at the very least, protects administrative action from excessive judicial intervention. Under the doctrine of deference, courts will be more reluctant to intervene in administrative decisions if such decisions relate to the administrative agency's area of expertise, among other things. ${ }^{54}$ Yet it is not clear that the standards of review for administrative decision-making are applied in any coherent or predictable fashion. ${ }^{55}$ So it seems as though administrative action will always be reviewable or potentially reviewable by the courts. Little is known about how administrative agencies might respond to the constant threat of judicial review or even how they apply case law to their own actions ${ }^{56} \mathrm{As}$ such, we cannot be sure that the current model of judicial oversight actually works. ${ }^{57}$

Consequently, administrative independence does not, cannot, and should not mean the same thing as judicial independence given the subordinate and circumscribed powers of administrative agencies. The argument that administrative tribunals, or that judicial functions of administrative bodies, should be subject to a rigorous standard of adjudicative independence is persuasive, but it is not always easy to separate judicial functions from

See e.g. Lorne Sossin, "Jurisdiction or Access to Administrative Justice? How the Supreme Court of Canada Missed the Point in Tranchemontagne," The Court (20 February 2007), online: <www.thecourt. $\mathrm{ca} / 2007 / 02 / 20 /$ jurisdiction-or-access-to-administrative-justice-how-the-supreme-court-of-canadamissed-the-point-in-tranchemontagne $>$ (noting how the Supreme Court focuses on statutory interpretation over the more pressing issues raised by Tranchemontagne v Ontario (Director, Disability Support Program), 2006 SCC 14, [2006] 1 SCR 513).

53 See e.g. Alice Woolley, "Legitimating Public Policy" (2008) 58:2 UTLJ 153 (arguing for procedural norms in the development of policy).

54 Dustin Kenall, "De-Regulating the Regulatory Compact: The Legacy of Dunsmuir and the 'Jurisdictional' Question Doctrine" (2011) 24:1 Can J Admin L \& Prac 115 at 116.

$55 \quad$ Ron Goltz, “Patent Unreasonableness is Dead. And We Have Killed it.' A Critique of the Supreme Court of Canada's Decision in Dunsmuir" (2008) 46:1 Alta L Rev 253 at 259. See generally Paul Daly, “Dunsmuir's Flaws Exposed: Recent Decisions on Standard of Review” (2012) 58:2 McGill LJ 483.

56 For an exception: see Sossin, "Rule of Policy," supra note 4; Jacobs, "A Wavering Commitment," supra note 4.

57 The recent case of Muhammad $v$ Canada (Minister of Citizenship and Immigration), 2014 FC 448, 454 FTR 161, suggests that it may not be working all that well. The 2014 decision was the second time Mr Muhammad had appealed the decision of a Minister's delegate that he would not be subject to torture if he was removed to Pakistan. Both times the Federal Court held that the delegate's decision was unreasonable because both times the delegate did not properly set out the evidence justifying their decisions. In both cases the Court sent it back for redetermination by a different delegate (see ibid at paras 192-93); Muhammad v Canada (Minister of Citizenship and Immigration), 2012 FC 1483, 423 FTR 242 at para 61. For a discussion of this case, including the independence issues raised in the 2014 decision: see Ron Ellis, "AN IGNIS FATUUS? The Rule of Law in the Administrative Justice System" (2015) 28:1 Can J Admin L \& Prac 55 at 57-79. 
administrative functions. In addition, some, but not all, administrative bodies are more closely tied with government policy than others. In his book, Ellis discusses his experience on the Ontario Workers Compensation Appeals Tribunal (WCAT) as Ontario moved from a left wing New Democratic Party government to a right wing Progressive Conservative government. The latter came to power with the promise to make welfare cuts and many expected the WCAT to be abolished or otherwise reformed. ${ }^{58}$ As undesirable as this may have seemed, until either adjudicative independence or welfare rights receive constitutional recognition, the WCAT is bound to be impacted by shifts in government policy. This particular shift in policy was also reflected by changes to the relevant legislation, which suggests a continued respect for the rule of law in that the government made its changes explicit and through the appropriate channels - it did not simply stack the tribunal with cronies. Ellis would likely disagree here, but administrative tribunals are not constitutionally protected and so they are subject to legislative reform or even abolition. This vulnerability raises questions about the applicability of a judicial model of independence to administrative tribunals. ${ }^{59}$ The changes the government made to the WCAT were legal, in accordance with the rule of law, and the result of an electoral mandate to make such changes, all of which makes them hard to impugn.

It is worth noting that even judicial independence exists largely because of political will. ${ }^{60}$ As such, administrative bodies, even where there are quasi-constitutional protections such as article 23 , are going to be in a weaker position than courts. ${ }^{61}$ Where such bodies are closely linked with government policies there is a need to make sure that they are accountable. What scholars (and perhaps also the public) want from administrative agencies is some guarantee that they will act fairly and that they will not be arbitrary. Without actually studying how administrative agencies operate, however, it is impossible to know whether or not they meet these standards of fairness. Roderick Macdonald argued that administrative agencies do develop their own "governing principles and commitments that are as real, permanent, and legal as those of the courts to guide them in the day-to-day exercise of what only appears on paper to be entirely unfettered discretion." 62 Of course such governing principles and commitments are indicative of, and so dependent on, institutional memory. If all or a significant number of an administrative body's personnel are replaced at once, then that institutional memory vanishes. ${ }^{63}$ As discussed in Part V, the ALCB did develop their own policies with respect to hotel licencing. Nonetheless, a study of the ALCB's relationship with the government shows that such procedures for decision-making existed alongside a care to defer to the government's wishes for the broader system of liquor sales. Before

Ellis, Unjust by Design, supra note 4 at 14-15.

Nathalie Des Rosiers, "Toward an Administrative Model of Independence and Accountability for Statutory Tribunals" in Madam Justice Gene Ann Smith \& Hélène Dumont, eds, Justice to Order: Adjustment to Changing Demands and Co-ordination Issues in the Justice System in Canada (Montreal: Éditions Thémis, 1998) 53 at 59-60.

Sossin, "Puzzle," supra note 6 at 6.

My point here is not meant to be normative. There are good reasons why a more professionalized and less ad hoc approach to administrative government in Canada is desirable but it can only come about as the result of political will.

Roderick A Macdonald, "Call-Centre Government: For the Rule of Law Press \#" (2005) 55:3 UTLJ 449 at 483. Willis made a similar observation in 1940: see John Willis, "Introduction - Administrative Discretion" in Willis, supra note 4,65 at 71 .

See e.g. the discussion of what happened with the Immigration and Refugee Appeals Board: Ellis, Unjust by Design, supra note 4 at 64-66. 
examining this aspect, it is necessary to set out the background to creating the ALCB, and the Board's enabling legislation.

\section{Creating the ALCB: CASh, CompleXity, AND CONTROVERSY}

The creation of the ALCB in 1924 came as the province shifted from prohibition to governmental liquor sales. Alberta's decision to end prohibition was controversial and its new system of liquor stores and hotel beer parlours marked the province as an outlier of sorts. The majority of other provinces remained under prohibition and, with the exception of Quebec, those that did allow legal liquor sales did not allow public drinking. ${ }^{64}$ Alberta's system of liquor sales was complex as well as controversial. This section argues that the ALCB was created in response to a range of pressures including the increased complexity of the new system of liquor sales, the controversial nature of legalized drinking, the cost of setting up the new system, and the government's experiences during prohibition.

Alberta did not have an independent liquor commission during prohibition despite demands to create one. ${ }^{65}$ As The Liquor Act ${ }^{66}$ made its way through the Legislature in 1916, Premier Sifton claimed that "[w]e can't get out of our responsibility as a government if we appoint a board of [liquor] commissioners: unless you pass a special act making the commissioners independent of the government and the legislature which would be an absurdity." ${ }^{\prime 67}$ Sifton's point was that a truly independent liquor commission was impossible; any commission would remain accountable to the government, simply because that was how such things worked. Yet with this statement Sifton failed to account for the creation of liquor boards elsewhere, and it comes across as an attempt to avoid having to create a similar board in Alberta. Sifton's argument may have been technically true but it also seems somewhat disingenuous, suggesting that the government had an ulterior motive for not creating a board.

The government's reluctance to create an independent board and its decision to leave the administration of The Liquor Act to the Attorney General's department was likely motivated by financial concerns. One week after the Act came into force on 1 July 1916, a government accountant wrote a memo to the Deputy Attorney General, Arthur G. Browning, detailing some financial issues. ${ }^{68}$ The memo appears in the files of the Liquor License Branch's accountant, and was likely part of the wrapping up process for the previous system of liquor laws. Browning appears to have asked whether two civil servants' telephones could be removed, presumably with the goal of saving money. Although the accountant wrote that the telephones in question could not be removed, he attached a list of expenditures covering items such as library books, postage, and other phones. With respect to these expenditures, the accountant noted that "I am unaware as to who first gave permission for this expenditure

Public drinking would eventually be legalized across the country, but with the exception of Alberta other provinces waited a few years before allowing public drinking to return: Heron, supra note 10 at 270.

The province did have boards of liquor commissioners prior to prohibition but these were municipal level boards: see Northwest Territories, Ordinances No 18 of 1891-92, An Ordinance respecting the sale of intoxicating liquors and the issue of licenses therefor, s 5; Heron, supra note 10 at 158.

SA 1916 (4th Sess), c 4.

"Estimates," supra note 2.

Memorandum from accountant to Mr Browning (8 July 1916), Edmonton, Provincial Archives of Alberta (RG 66.166, file 1225). 
to be charged to the Government, but it has been allowed for at least the last seven years." ${ }^{69}$ The impression given by this memo is a degree of penny pinching which fits with the broader financial pressures faced by Alberta at the time.

By 1917 , Alberta's debt stood at over $\$ 30$ million and would only grow as prohibition progressed..$^{70}$ The cost of policing increased under prohibition, not just because The Liquor Act was a costly endeavour, but because it coincided with the 1916 decision of the Royal North West Mounted Police (RNWMP) to withdraw from ordinary policing. The RNWMP's withdrawal meant that for the first time Alberta had to pay all its own policing costs. Initially Alberta could only afford 155 Alberta Provincial Police (APP) officers compared to the 312 deployed by the RNWMP. ${ }^{71}$ Throughout the eight years of prohibition, Alberta would remain unable to provide adequate numbers of police officers and the province's policing issues were constantly linked with the alleged deficiencies of prohibition enforcement. ${ }^{72}$

The agricultural crisis which gripped the southern half of the province following the end of the First World War added further pressure to Alberta's finances. ${ }^{73}$ In response to this crisis and the provincial government's failure to adequately respond to it, the United Farmers of Alberta (UFA) opted to become a political party. The UFA, formed in 1909, had advocated a range of political and social reforms prior to entering electoral politics themselves. These reforms included prohibition as well as electoral reforms such as direct legislation and proportional representation. Upon becoming a political party in 1919, the UFA experienced rapid success and won the 1921 provincial general election. ${ }^{74}$ The UFA's primary political goal may have been to aid the drought stricken farmers, but they also vowed to do something about prohibition as by 1921 there was widespread belief that The Liquor Act was poorly enforced. ${ }^{75}$ Oddly, the UFA, despite their earlier calls for an independent liquor commission to enforce The Liquor Act, did not set up such a commission upon their election. $^{76}$

Ibid.

"Women Electors of City Hear Candidates of Both Parties at Big Meetings Yesterday," Edmonton Bulletin (31 May 1917) 4.

Zhiqiu Lin, Policing the Wild North-West: A Sociological Study of the Provincial Police in Alberta and Saskatchewan, 1905-32 (Calgary: University of Calgary Press, 2007) at 53.

Letter from WH Erant to Attorney General Brownlee (21 October 1923), Edmonton, Provincial Archives of Alberta (RG 75.126, file 3728); "Will Not Prosecute Delaney," Blairmore Enterprise (11 November 1920) (here the Enterprise called for police reform to improve prohibition enforcement); Heron, supra note 10 at 235-36. In the US prohibition enforcement was also chronically underfunded and ignored: see Scott Schaeffer, "The Legislative Rise and Populist Fall of the Eighteenth Amendment: Chicago and the Failure of Prohibition" (2011) 26:3 JL \& Pol 385 at 386, 388, 413; Richard N Kottman, "Volstead Violated: Prohibition as a Factor in Canadian-American Relations" (1962) 43:2 Can Historical Rev 106 at 115 .

See David Bright, "1919: A Year of Extraordinary Difficulty” in Michael Payne, Donald Wetherell \& Catherine Cavanaugh, eds, Alberta Formed Alberta Transformed, vol 2 (Edmonton: University of Alberta Press, 2006) 412; David C Jones, Empire of Dust: Settling and Abandoning the Prairie Dry Belt (Calgary: University of Calgary Press, 2002).

Howard Palmer \& Tamara Palmer, Alberta: A New History (Edmonton: Hurtig Press, 1990) at 194-96. See e.g. Sarah E Hamill, "Making the Law Work: Alberta's Liquor Act and the Control of Medicinal Liquor from 1916 to 1924" (2012) 27:2 CJLS 249 at 260.

“Ask Commission to Administer New Liquor Act," Edmonton Bulletin (21 January 1916) 1; AW Coone, Letter to the Editor, Claresholm Advertiser (2 March 1916) 4; "To Handle Sale of Liquor," Bow Island Review (17 December 1920) 5. 
The UFA may have failed to create a liquor commission simply because they thought they could do a better job. ${ }^{77}$ After all, the UFA were staunch Prohibitionists and like many Prohibitionists they believed that it was the government's fault prohibition was not working. In 1917, for example, the then opposition leader, Edward Michener, promised "an independent [liquor] commission absolutely free from political influence."78 Michener's promise was likely an attempt to curry favour with the Prohibitionists, some of whom believed the government and others responsible for prohibition were working against it. In fact, in 1918, the accusations of leading Prohibitionists forced APP Superintendent A.E.C. McDonnell to take to the press to defend his men against claims that they failed to enforce prohibition. ${ }^{79}$ Such accusations recurred throughout prohibition and at one stage even saw Nellie McClung, MLA, blame cabinet ministers for the lax enforcement of The Liquor Act, a claim which they furiously denied. ${ }^{80}$

Granted, there is some evidence to suggest senior staff members in the Attorney General's Department were opposed to prohibition. Deputy Attorney General Arthur Browning, for example, once wrote a letter to each Chief of Police in Alberta's cities which observed that "[i]n your opinion and mine the Liquor Act may be one that should not have been passed." 81 He then went on to say that "but so long as it [the Act] is law, it must be enforced and your earnest co-operation in this respect will be appreciated." 82 Browning's comments reveal a degree of antipathy towards prohibition, but they also show a desire to uphold the law no matter what that law was. Browning's letter also suggests that anti-prohibition feeling was widespread, though in response, Edmonton's Chief Constable Shute asserted that he had always voted for prohibition and strongly denied any claims of "an understanding between the Police and the offenders. ${ }^{, 83}$ Shute objected, as other police chiefs had, to the idea that the police were somehow to blame for prohibition's failures. ${ }^{84}$

Yet, even with good Prohibitionists such as the UFA in office, prohibition continued to face the same issues as it had done under the Liberals. The new Attorney General, John E. Brownlee, explained the continued prohibition failures by arguing that people had learned "how to evade the present Liquor Act and we are now getting the full benefit of their experience." ${ }^{\prime 85}$ Although Brownlee maintained that the government was trying to find a way to make prohibition enforceable, it was clear that the problems with The Liquor Act went deeper than simply a lack of an independent body to administer it.

The UFA did create a commission of sorts in 1922 by instituting the office of "Liquor Act Commissioner." The Liquor Act Commissioner's job was, however, limited to promoting compliance with prohibition and left control of prohibition enforcement with the Attorney General's department: see "Brownlee Tightens Up Act," Lethbridge Herald (16 March 1922) 1; "Departmental News from the Capital," United Farmers of Alberta (15 June 1922) 16.

Edward Michener, “A Brief Review of Provincial Affairs,” Red Deer News (23 May 1917) 6.

APP Superintendent AEC McDonnell, "Liquor Act Enforcement," Letter to the Editor, Edmonton Bulletin (16 March 1918) 24.

"Blames Ministers for Liquor Act Failure," Redcliff Review (17 March 1921) 1.

See e.g. Letter from Browning to Chief Constable Ritchie of Calgary (8 September 1921) Edmonton, Provincial Archives of Alberta (RG 75.126, file 3246).

Ibid.

Letter from Chief Constable Shute to AG Browning (10 September 1921), Edmonton, Provincial Archives of Alberta (RG 75.126, file 3246).

The APP Chief Constable had, for example, been forced to defend his men as early as 1918 from accusations of non-enforcement: see McDonnell, supra note 79.

Letter from Brownlee to WH Shields (31 October 1921), Edmonton, Provincial Archives of Alberta (RG 83.192, file 410). 
By the 1920s, public opinion in Alberta was slowly turning away from prohibition but the province's Prohibitionists remained vocal and active in their support of the measure. Among the UFA's own members support for The Liquor Act ran high, meaning it was all but impossible for the government to end prohibition on its own initiative. Instead, the government facilitated a vote over the measure's future via the Direct Legislation Act; ${ }^{86}$ an Act the UFA had itself campaigned for prior to entering electoral politics. ${ }^{87}$ The resulting plebiscite saw Alberta vote to end prohibition and replace it with a system of government liquor stores and public beer parlours.

A few weeks after the vote, the Edmonton Bulletin came out in favour of a liquor commission to administer the new Act: "Conceivably the new law might be administered as is the present one, directly under the department of the Attorney General. The success of that method is doubtful." $" 88$ The Bulletin observed that the likely complexity of the new system of liquor sales "will comprise a task too large to be imposed upon the officials of one section of a Government department," and cited to the example of other provinces' liquor commissions as an alternative.$^{89}$ Here the Bulletin was correct, as the new liquor system was both a business and a regulatory system, dealing with questions of supply, demand, and pricing, as well as assessing which hotels should be licenced, and who should and should not be allowed to drink and why. ${ }^{90}$ In short, the new system of liquor control was riddled with minutiae, and leaving it to a government department to administer such a system could have led to accusations of political favouritism in granting and revoking licences.

The political controversy surrounding Alberta's new system of liquor sales offered another reason for delegating the administration of it to an independent board. Histories of other early administrative agencies highlight the controversial nature of their subject matter and point to a desire to remove such subjects from politics. ${ }^{91}$ A body like the ALCB allowed the government to appear one step removed from liquor control, much as the use of the Direct Legislation Act had removed the decision to end prohibition from the government, or at least appeared to remove it. ${ }^{92}$

The other reason behind creating the ALCB was more directly linked to financing. Setting up a system of liquor sales involved considerable expense: buying the necessary stock, paying rent for the stores and warehouses, and so on. In 1924, Alberta did not necessarily have the cash on hand to pay for it; and, or so the rumours went, the government needed a large bank loan to pay for the initial expenses. Such was the extent of the loan that the bank in question was alleged to have demanded that one of its own men was put in charge in order to make sure the system was profitable. Although the government strongly denied such

SA 1913 (4th Sess), c 3.

See Bradford James Rennie, The Rise of Agrarian Democracy: The United Farmers and Farm Women of Alberta, 1909-1921 (Toronto: University of Toronto Press, 2000) ch 5 at $110 \mathrm{ff}$. I have also discussed Alberta's experiences with direct legislation elsewhere: see Sarah E Hamill, "Prohibition Plebiscites on the Prairies: (Not-So) Direct Legislation and Liquor Control in Alberta, 1915-1932" (2015) 33:2 L \& Hist Rev 377 [Hamill, "Prohibition Plebiscites"].

"The Liquor Commission,” Edmonton Bulletin (24 November 1923) 9.

Ibid.

The exceptions here were those statutorily forbidden from drinking because they were minors or Status Indians.

See e.g. Benidickson, supra note 5 at 1222-51; Willis, "Foreword," supra note 4 at vi-vii. See Hamill, "Prohibition Plebiscites," supra note 87. 
rumours and insisted that the Chairman of the ALCB had been chosen because of his qualifications, ${ }^{93}$ their choice was, as some newspapers noted, a "dark horse." 94

The first ALCB Chairman, and sole board member for several years, was Robert J Dinning. Prior to his appointment Dinning worked as the manager of the Lethbridge branch of the Bank of Montreal, ${ }^{95}$ the very bank later alleged to have loaned the government the money to create the ALCB. ${ }^{96}$ Dinning had not cut much of a public figure before 1924 and his views on liquor control had, or so he claimed, shifted with those of the rest of the province: voting in 1915 for prohibition and then voting to end it in $1924 .{ }^{97}$ Dinning was not an expert in temperance; he was an expert in finance. The press reported that the provincial cabinet had unanimously approved Dinning once the Premier had explained why he was qualified, but those qualifications were never made public. ${ }^{98}$ Dinning's appointment may have been linked with the bank loan or it may simply have been because the government wanted and needed liquor sales to be a financial success. ${ }^{99}$

Yet, as will become clear in Part V, the financial aspect of the ALCB was a sore point for the government. Many Prohibitionists felt that the government cared more about revenue than the health and well-being of the people, a claim which the government always denied and which influenced its relationship with the ALCB. As such, the creation of the apparently independent ALCB was only a partial success in shielding the government from association with liquor sales. Before examining the relationship of the government and the ALCB in more depth, it is necessary to briefly examine the Board's enabling legislation. The ALCB may have been separate from government but separate did not mean, and was not intended to mean, complete independence.

\section{The Liquor Control ACt AND the ALCB}

Reginald Hose, writing in the 1920s, noted that provincial liquor boards "could scarcely be less circumscribed." 100 The powers of the boards "cover a wide field of active management and quasi-judiciary action," 101 and "an implied confidence in their personnel is markedly evident in the duties entrusted to them by the various Legislatures."102 Put simply, liquor boards, including the ALCB, seemed to have vast powers to do a wide range of actions. Hose appeared to rely solely on the various provincial liquor acts in making his assessment of the powers of liquor boards. Yet a close reading of the Liquor Control Act suggests that while it did grant the ALCB significant powers, these powers were supervised

\footnotetext{
93 "No Strings Tied to Appointment of Liquor Chief," Calgary Herald (23 May 1924) ["No Strings Tied"].

94 "Dark Horse Lands Liquor Commissioner Job at \$9,000 Per Year,” Macleod Times (31 January 1924) 1.

"Dinning Appointment Warmly Commended Lethbridge Citizens Endorse Selections ; Is Business Man of Extended Experience," Lethbridge Daily Herald (30 January 1924) 7.

"Former Wetaskiwin Man to be Liquor Commissioner," Wetaskiwin Times (31 January 1924) 1.

“Alberta Needs New Revenue Sources; Budget Is Sure To Show Big Deficit,” Lethbridge Daily Herald (14 February 1923) 1.

100 Reginald E Hose, Prohibition or Control? Canada's Experience with the Liquor Problem 1921-1927 (New York: Longmans, Green \& Co, 1928) at 7.

Ibid at 6-7.

Ibid at 7 .
} 
in a number of ways. This section outlines what the Act had to say about the ALCB's powers and relationship to the government.

The Act made the ALCB responsible for regulating all aspects of liquor consumption in Alberta. This included the power to decide where to set up stores and to grant, suspend, or cancel licences and permits. ${ }^{103}$ The Act did not require the ALCB to give reasons for any suspensions or cancellations and there was no appeal from the Board's decision. ${ }^{104}$ Attempts to preclude judicial review of administrative action were common among early administrative bodies and often failed. ${ }^{105}$ I found no evidence of judicial review of an ALCB decision during its first 15 years; but, as the next section shows, there were alternative ways to review the Board's decisions. Although there was no judicial review, the Act did require the Board to provide the legislative assembly with detailed annual reports covering the business of each vendor, the profits and loss of the Board as a whole, and information about law enforcement. ${ }^{106}$ The requirement for such detailed reports suggest a degree of supervision over the ALCB; but, given what the Board was tasked with, such supervision would have been minimal and after the fact.

Continued government supervision was also suggested by the Act's comments about ALCB Board members. Under the Act, the Board could have one, two, or three members, but the government retained discretion over who sat on the Board, the quorum of the Board, and the members' salaries. ${ }^{107}$ Board members held at-pleasure appointments, meaning that they could be removed at any time for any reason. At-pleasure appointments might seem to undermine the idea of administrative independence but that assumes that administrative independence is identical to judicial independence. Granted the ALCB was, in part, created to separate the liquor laws from politics, but the ALCB remained under government supervision. It was neither designed nor meant to be completely independent. The ALCB had to act within the parameters set out by the Liquor Control Act and at-pleasure appointments likely offered one way for the government to ensure the Board stuck to its mandate.

The Act's provisions about issues which are today considered central to discussions of administrative independence are remarkably sparse. The Act makes no comment about how long Board members should be appointed for, offers no procedures to follow in appointing Board members, and no guidance on salary other than " $\mathrm{t}]$ he Lieutenant Governor in Council shall ... [f]ix the salaries of members of the Board." "Granted, the ALCB was not solely an adjudicative tribunal, but its licensing decisions could and did have a serious impact on an individual's livelihood. Such limited structural guarantees for the ALCB were likely a result of the government's own uncertainty over whether the Board would survive. ${ }^{109}$

Liquor Control Act, supra note 1, ss 9-10.

Ibid, s 148(2).

David Dyzenhaus, "Dignity in Administrative Law: Judicial Deference in a Culture of Justification" (2012) 17:1 Rev Const Stud 87 at 99. For a contemporary discussion of the courts' actions: see John Willis, "Statute Interpretation in a Nutshell: Preliminary Observations" (1938) 16:1 Can Bar Rev 1. Liquor Control Act, supra note 1, s 137.

Ibid, ss 4, 6 .

Ibid, s 6 (c)

In fact, Willis hypothesized that the temporary nature of boards was one of the reasons they were so popular in Canada compared to England, which simply expanded the size of the civil service: Willis, "Foreword," supra note 4 at vi. 
Aside from detailing the number of Board members and the need to deliver an annual report, the Act also offered some additional limits to the ALCB's discretion. All of the ALCB's regulations had to be approved by the Lieutenant-Governor-in-Council, suggesting yet further government oversight of the Board's mandate. ${ }^{110}$ The Act also limited the kinds of premises which could be considered hotels for the purposes of a hotel beer licence and limited the number of hotels which could be licenced based on the size of the local population. ${ }^{111}$ Such limits left room for the ALCB to further restrict what counted as a hotel, but were designed to prevent an excessive number of hotel beer parlours. ${ }^{112}$ They were a reminder that the Act was about control not about the free sale of liquor. As I now move on to show, this duality - the need to balance control with profit and the continued skepticism of the government towards liquor - made for an ALCB which sometimes seemed insecure and looked to the government even when not strictly required by the Act.

\section{CAUtion, OVERsight, AND ThE LiQuOR BUSINESS: THE ALCB'S RELATIONSHIP WITH THE GOVERNMENT}

As the ALCB was a statutory delegate it should come as no surprise that the government exercised control over it. What is more surprising is that the ALCB would often seek government approval where it was not necessarily needed. The ALCB's caution may have been due to the novelty of the Board and Dinning's own relative lack of experience with running such a body. Yet Dinning's hesitancy here may also have stemmed from the ALCB's uncertain future and the continuing controversy surrounding Alberta's system of liquor sales. This section examines the ALCB's relationship with government and how this relationship influenced the way the ALCB operated.

The ALCB may have been apparently separate from the government, but perhaps in an effort to save money or to ensure continued oversight of the Board, the Attorney General's department provided all of the ALCB's legal advice. The department put two solicitors in charge of answering any questions that the Board might have about its powers or the appropriate course of action. ${ }^{113}$ In practice, the Board's correspondence with these two solicitors meant that most Board regulations were drafted by these solicitors rather than the Board. In 1924, for instance, one of the department's solicitors drafted the letter about whether or not it was legal to produce wine at home. The Board then sent this form letter to anyone who asked if they could make wine at home. ${ }^{114}$

By providing the Board with legal advice, the Attorney General's department could shape how the ALCB understood the Liquor Control Act and the powers it enjoyed. As such the department retained much stricter oversight of the ALCB than was immediately apparent. Presumably the ALCB could have consulted with a separate law firm and it is not clear

110 Liquor Control Act, supra note 1, s 10.

Ibid, s 33 .

As indeed the Board did in its own regulations: see Regulations under the Government Liquor Control Act of Alberta, OC 604-24 (1924) A Gaz, 302 at 320.

113 Memorandum from the Attorney General to Mr Gray (17 June 1924), Edmonton, Provincial Archives of Alberta (RG 75.126, file 3745). The two solicitors were WS Gray and Mr Frawley. Almost all of the correspondence I came across was from WS Gray or a "solicitor in the attorney general's department."

114 Letter from Solicitor in the Attorney General's department to AJ Mason (24 June 1924), Edmonton, Provincial Archives of Alberta (RG 75.125, file 2566c). 
whether Dinning asked the department for such assistance or whether the department suggested it. On occasion, the Attorney General asked to read over the memos that the solicitors were sending to the ALCB. In June 1924, for example, Attorney General Brownlee wanted to read the solicitors' memo about the procedure for local option votes (votes whereby municipalities could ban liquor sales within their boundaries) "as there may be certain questions of policy involved." ${ }^{115}$ Brownlee's comments here suggest that he may have insisted on offering such legal advice to the ALCB and highlights a desire to ensure the Board followed, or at least did not contradict, government policy.

Yet the ALCB would also seek government approval where it was not strictly needed. For example, the Liquor Control Act gave the ALCB the power to sign leases, but, in practice, the Board sought government approval before signing any lease. ${ }^{116}$ In 1924 ALCB Chairman Dinning wrote to Deputy Attorney General R.A. Smith to inform him that "it is the intention of the Board to have all leases covering properties required by us executed by the Minister of Public Works." Dinning went on to outline the Board's wishes for the properties which included the power to make changes to the property, to use the property "for any purpose we may deem necessary," and to refuse the lessor's right to enter and view the property unless it was at a time convenient for the Board. ${ }^{117}$ When the Board's first leases came up for renewal in 1927, the Board once again sent its requests to the Minister of Public Works via the Attorney General's department. ${ }^{118}$ As a result, the Attorney General's department could see where the ALCB's stores were and had the power to intervene if it did not approve of the store location. I did not find any evidence that the government refused to approve any lease for the ALCB, but nor did the government refuse to get involved with leases. It is possible that given his lack of legal background, Dinning was unsure of how to word the lease agreements that he required, or that he wanted to ensure that he could actually get the lease terms he sought. Whatever the reason for his decision to seek government approval over store leases, it had the effect of allowing the government to approve the locations of liquor stores.

In contrast to the situation with liquor stores, the government explicitly refused to get involved with hotel licences. Every so often a disgruntled former licensee, usually one who had lost their licence to a more modern hotel, would attempt to get the government involved in the ALCB's licencing decisions. In 1933, for example, the ALCB's decision not to renew the Coaldale Hotel's licence in face of competition from a newer hotel, lead to the Legislature discussing an amendment to the Liquor Control Act. ${ }^{119}$ The Board noted that it was following its own policy to license only the best hotels and that without such a policy there would be no incentive to improve hotels. ${ }^{120}$ Such a policy was neutral, clear, and not motivated by any political considerations with respect to the licensee. ${ }^{121}$ In the Legislature, Premier Brownlee spoke out against the amendment lest it encourage everyone who had lost

Memorandum from Brownlee to Mr. Gray (18 June 1924), Edmonton, Provincial Archives of Alberta (RG 75.126, file 3745).

Liquor Control Act, supra note 1, s 9(e).

Letter from Dinning to Smith (13 March 1924), Edmonton, Provincial Archives of Alberta (RG 75.126, file 3326).

Memorandum from the Attorney General's Department to the Department of Public Works (19 March 1927), Edmonton, Provincial Archives of Alberta (RG 75.126, file 3323).

"Liquor Act Revision Is Considered," Lethbridge Herald (31 March 1933) 1.

"Marquis Hotel Beer License Under Fire; Dinning On Stand," Lethbridge Herald (29 March 1933) 7.

Compare with the situation in Roncarelli, supra note 40. 
their licence to petition for an amendment and thus lead to the Legislature's time being wasted on licencing issues. ${ }^{122}$ The proposed amendment failed to pass and the government refused to change or criticize the ALCB's policy of licencing the best, most up-to-date hotels. ${ }^{123}$ While the Coaldale incident might seem to represent some interference with the ALCB's licencing policies, it was nothing more than a review of the ALCB's policies and one which left these policies unchanged. It showed that the Legislature could review the ALCB's decisions but it also showed why that would be a bad idea. Crucially, it also showed that the ALCB had developed a clear policy for licencing hotels and one which was communicated to licensees.

Hotel licences and the public drinking they allowed were the most controversial aspect of the new system, which may explain the government's hands-off approach. It is reasonable to conclude that the government, particularly one that claimed to be pro-prohibition, would want to separate itself as far as possible from public drinking. In addition to their controversial nature, hotel beer licences required such close monitoring that any government or legislative intervention over who received a licence threatened to upset the ALCB's regulatory balancing act. The Coaldale Hotel incident showed that Brownlee feared that if one amendment passed, the Legislature's time would be dominated by aggrieved former hotel licensees. No government minister would have been able to weigh the competing factors in the way that the ALCB did when it decided which hotels to licence. The government's decision not to interfere with the ALCB's judgment over licences should be understood as a desire to avoid an issue that was both controversial and time consuming.

In contrast to hotel licences, the ALCB's leasing issues centred on the Board's system of liquor stores and these represented a significant outlay both in terms of stock and store fittings. ${ }^{124}$ Given its level of investment as well as the increasing importance of ALCB profits to the provincial budget, the government kept a close eye on the financial side of the ALCB. In addition to the annual reports, the government received monthly updates on the ALCB's accounts from 1926 to 1929 . These reports are relatively sparse and simply outline the Board's profit and if it was less than the year before. ${ }^{125}$ The government clearly had an interest in making the ALCB as profitable as possible, and as the bulk of the Board's profits came from liquor stores not hotel licences, the government wanted to closely monitor the operation of liquor stores. Furthermore, Alberta's liquor stores were called "government liquor stores," which meant that they were more obviously associated with the government than beer licences were, as the latter only had to display their ALCB licence rather than any

122 "Defeat Bill to Amend Alta. Liquor Act," Lethbridge Herald (5 April 1933) 1.

123 Dinning outlined this policy: see Letter from Dinning to WE Alford (8 February 1933), Edmonton, Provincial Archives of Alberta (RG 69.289, file 99a) ("[ t $]$ he Board's attitude in the Lethbridge situation is identical with the policy adopted at Calgary, Edmonton and other smaller points in the Province, that is, to give beer selling privileges to the hotels offering the greatest service to the public, all other things being equal").

124 According to the ALCB's first annual report, the Board had over \$1 million worth of stock and almost $\$ 40,000$ worth of equipment: Alberta, Legislative Assembly, "First Annual Report of the Alberta Liquor Control Board, 1924" in Sessional Papers (1925) at 13-18.

125 Reports and Accounts Alberta Liquor Control Board, Edmonton, Provincial Archives of Alberta (RG 69.289 , file $121,122 \mathrm{~b}$ ). It is possible that the government always received such reports but these are the ones I found in the archives. 
association with the government. ${ }^{126}$ Though both stores and licenced premises were in the paradoxical situation of regulating and selling alcohol, given the stores' apparent links with the government the paradox was, arguably, more evident there.

In addition to the obvious forms of control, the government also offered the ALCB implicit guidelines. The government repeatedly suggested that government control of liquor would only exist so long as the public wanted it to. Such references to the public will excused the government's own actions in ending prohibition and gave hope to the Prohibitionists that one day prohibition might return. Yet the government's comments about public opinion also told the ALCB that they needed to please the public and answer any criticism of Alberta's liquor system.

As the most organized and vocal section of Alberta's public remained the Prohibitionists, the ALCB was far more likely to hear and act on their views of the liquor laws. The government seemed to share the hopes of the Prohibitionists that prohibition would return, placing further pressure on the ALCB to make the Liquor Control Act's control of liquor a success. In 1926, for example, Premier Brownlee refused a request to allow ALCB staff to be included in the civil servants' superannuation scheme because "the Government Liquor Control Act may be of a temporary nature only." 27 Three years later, Brownlee predicted that Alberta would return to temperance and warned beer licensees that there was strong feeling against them. ${ }^{128}$ The government's repeated mention of the public will served to push the ALCB towards stricter implementation and reminded the ALCB that it had to please the public or face abolition.

Brownlee's 1929 comments about Alberta going back to temperance cannot be taken at face value. As I have noted elsewhere, his prediction emerged during a meeting with the province's Prohibitionists who were frustrated by their lack of progress. ${ }^{129}$ The Prohibitionists were in almost constant contact with the government during the late 1920s and they seemed to think that they were working in tandem with the government to secure a return to Prohibition. Invigorated by Brownlee's February 1929 prediction, the Alberta Prohibition Association wrote to Brownlee with their plans to restart their publication, Searchlight, and asked if the government wanted to buy advertising space. ${ }^{130}$ A year later, H.H. Hull of the Prohibition Association suggested that the government should bring a test case to see if the province controlled liquor manufacturing so that "temperance forces" would see some progress. ${ }^{131}$ Hull's letter shows that Alberta's Prohibitionists were not making

126 Brief of the Alberta Liquor Control Board to The Special Committee of the Alberta Legislature appointed to review the Liquor Control Act (27 August 1956), Edmonton, Provincial Archives of Alberta (RG 69.289, file 2132a) at 6 (suggests renaming "Government Liquor Stores" to "Alberta Liquor Stores"); Liquor Control Act, supra note 1, s 34 (3) ("[e]very license shall be constantly and conspicuously exposed in that part of the hotel specified in the license where beer may be kept, sold and consumed, under such license").

127 Letter from Premier to HT Sullivan, General Secretary of the Civil Service Association (20 April 1926), Edmonton, Provincial Archives of Alberta (RG 69.289, file 130a). "New Liquor Control Law Due Within Two Years, Premier Says," Calgary Daily Herald (27 February 1929) 1 ["New Liquor Control Law"].

Hamill, "Prohibition Plebiscites," supra note 87 at 404.

130 Letter from HH Hull to Brownlee (31 July 1929), Edmonton, Provincial Archives of Alberta (RG 69.289, file 98 b).

131 Letter from HH Hull to Brownlee, (25 March 1930), Edmonton, Provincial Archives of Alberta (RG 69.289, file 99a) [Letter to Brownlee, March 1930]. 
progress, suggesting that the majority of Albertans disagreed with them. Public opinion was not on the side of prohibition but by October 1930 the Prohibitionists had begun their ultimately unsuccessful attempt to have a plebiscite on the beer parlours. ${ }^{132}$

The beer parlours and the public drinking they represented were the most controversial aspect of Alberta's post-prohibition liquor system. Although all other provinces would eventually create their own beer parlours, in 1930 most other provinces only allowed for liquor stores. ${ }^{133}$ To bolster their demands for the abolition of beer parlours, Prohibitionists relied on the argument that the parlours did not provide much provincial revenue. Hull even suggested that "the closing of the Beer Rooms would increase rather than decrease the Provincial Revenue from the sale of liquor." 134 Brownlee did not appreciate this line of argument and denied that money had anything to do with the liquor laws. ${ }^{135}$

Despite evidence that most of the public did not want a return to prohibition the ALCB seemed anxious about its future and took steps to refute the Prohibitionists' claims. While the ALCB never openly defended the beer parlours, even to government ministers, the Board did strongly imply that the public accepted the beer parlours and that they were necessary. First, in July 1929, almost four months after Brownlee's comments about Alberta returning to temperance, Dinning forwarded a report on Alberta's beer parlours to Brownlee. An anonymous UFA man who had "in the past complained [about] the beer-rooms" ${ }^{136}$ wrote the report and noted that most people were apathetic yet accepting of the beer rooms, a situation the author attributed to increased enforcement and tighter regulations. Secondly, the ALCB's Sixth Annual report, issued in 1930, mentioned both the Prohibitionists' agitation against the beer parlour and the high quality of Alberta's hotels. ${ }^{137}$ Of course, in defending the beer parlours and their associated hotels, the ALCB was also defending its own record and that of its licensees.

In light of the government's comments over the importance of public opinion it is not surprising that the ALCB sought to protect and defend its own reputation and the reputation of those businesses associated with it. The ALCB would, at times, go to great lengths to investigate allegations made against it. In 1931, for example, the ALCB dispatched an undercover detective to investigate claims that Otto Morin of Jasper's Pyramid Hotel was

"Executive of Moderation League of Alberta Held Session to Consider Action of Prohibition Association- Record of Liquor Control Act is Considered to be Satisfactory in Every Respect," Macleod Times (23 October 1930) 1. For more on this attempt at a plebiscite see Hamill, "Prohibition Plebiscites," supra note 87 at $402-409$.

133 Heron, supra note 10 at 270.

134 Letter to Brownlee, March 1930, supra note 131.

135 Letter from Brownlee to Hull (26 March 1930), Edmonton, Provincial Archives of Alberta (RG 69.289, file 99a). Hull's observation about the profits from hotel beer parlours was likely correct. The licencing fee varied depending on the size of the settlement where the hotel was located. The minimum fee was at least \$210 with the maximum being \$410 (Liquor Control Act, supra note 1, s 38). The ALCB did not list the profits it made from licences alone but using the 1929 figure of 378 hotel licences issued, these licences would have yielded between $\$ 79,380$ and $\$ 154,980$. In 1929 , the sale of liquor permits (a prerequisite for buying liquor from liquor stores) alone raised $\$ 197,203.50$. The ALCB's net profit for 1929 was $\$ 2,410,886.38$. Thus the revenue from hotel beer licenses likely accounted for less than 10 percent of the Board's profits: see Alberta, Legislative Assembly, "Sixth Annual Report of the Alberta Liquor Control Board, 1929" in Sessional Papers, No 3 (1930) at 6-7, 11 [Sessional Papers No 3]. Alberta Liquor Control Board, "Report on the Beer-Room and Dining-Room Situation," forwarded to Brownlee by Dinning (6 July 1929), Edmonton, Provincial Archives of Alberta (RG 69.289, file 98b).

137 Sessional Papers No 3, supra note 135 at 7. See also Hamill, "Prohibition Plebiscites," supra note 87 at 406 . 
"scandalizing the Board." ${ }^{138}$ According to anonymous reports made to the ALCB, Morin had complained that the Board was unfair because his hotel had only received a six-month licence rather than one for a full year. This situation arose because Jasper was, and still is, a resort town whose population fluctuates and a six-month licence allowed Jasper's licenced hotels to reflect this change in population and the fact that many of Jasper's amenities closed in the winter. The ALCB detective posed as a man thinking of buying a hotel and reported that Morin made no comments about the Board being unfair, though the hotel's secretary thought that the Pyramid only got a half-year licence because the other hotel had more political influence. ${ }^{139}$ Dinning denied this claim and asserted that the hotel with the full-year licence was more up to date. ${ }^{140}$

The Morin incident illustrates the lengths to which the ALCB would go if a person made allegations against them, and reflects the Board's desire to appear respectable to, and be respected by, the public. It is hard to see how one hotel licensees' accusation of the Board being unfair could hurt the ALCB's operations, but the Board took its reputation seriously enough to investigate. Yet the Morin incident could also be understood as an attempt to protect the ALCB's reputation among hotel licensees. As with Lethbridge's Coaldale Hotel, the Board wanted to appear impartial and to be seen as making licencing decisions based on hotel quality rather than political favours. Notably, Dinning communicated the results of the Board's investigation to the government which suggests that the government also wanted to separate licencing decisions from politics.

The ALCB's concern with ensuring its licencing decisions were seen as politically neutral echoes of what the Supreme Court of Canada has said about judicial impartiality. The Court has held that even the appearance of bias is enough to taint the judicial process. ${ }^{141}$ Actual bias is, of course, hard to prove and the Court does not apply such a rigorous standard to administrative decision-makers, even in adjudicative contexts.

The ALCB may not have been politically biased in the context of granting hotel licences but it was racist. In its early years, the ALCB had a policy against licencing hotels run by Chinese Canadians, ${ }^{142}$ though the Board violated its own policy and licenced one Chinese Canadian: Charlie Wing of Spirit River. ${ }^{143}$ The main reason the Board licenced Wing was that he had the support of the population in Spirit River. ${ }^{144}$ Wing proved to be a good licensee

Alberta Liquor Control Board, Report from Operative No 10 (7 May 1931), Edmonton, Provincial Archives of Alberta (RG 69.289, file 99a).

Ibid.

Letter from Dinning to Premier Brownlee (16 May 1931), Edmonton, Provincial Archives of Alberta (RG 69.289, file 99a).

Wewaykum Indian Band v Canada, 2003 SCC 45, [2003] 2 SCR 259 at para 66.

Letter from Dinning to George F Peek (5 June 1924) Edmonton, Provincial Archives of Alberta (RG 74.412, file 2387).

Memorandum from Dinning to J Forster of the Licence Department (23 August 1924), Edmonton, Provincial Archives of Alberta (RG 74.412, file 2387).

Telegram from Dinning to WE Davis (7 August 1924), Edmonton, Provincial Archives of Alberta (RG 74.412, file 2387); Telegraph from Spirit River community members to Dinning (22 August 1924), Edmonton, Provincial Archives of Alberta (RG 74.412, file 2387); Alberta, Report of Inspector on Hotel Application (12 November 1925), Edmonton, Provincial Archives of Alberta (RG 74.412, file 2387). As early as 1922, Wing and his hotel received praise in the Edmonton Bulletin with the Bulletin describing Wing as "far-sighted" and "public spirited" with his hotel being the "wonder of all visitors. The finest hotel in the north country is the general verdict" ("Spirit River is Better Village Being Rebuilt," Edmonton Bulletin (2 March 1922) 5). 
and ran an excellent hotel, yet the Board refused to grant him a second licence for the neighbouring village of Fairview because the population there was opposed to any Chinese Canadian being licenced. ${ }^{145}$ The ALCB's actions with respect to Wing suggest that its racist licencing policy reflected anti-Chinese feeling among Alberta's population. ${ }^{146}$ This is not meant to excuse the ALCB's refusal to licence Chinese Canadian hotels; however, it does act as a further illustration of the Board's concern with public opinion, even if that public opinion was offensive.

Furthermore, the Board knew that its policy was deeply questionable and potentially open to challenge. In 1924, J. McKinley Cameron, the lawyer for Lai Noon, a hotel owner from Craigmyle, wrote to the ALCB to say that if his client would never get a licence because of his race then they should say so, in order that Noon could sell his hotel instead of continuing to operate under unfair conditions. The ALCB, having initially told Cameron that it was adverse to such applications, then told Cameron that they had already granted a licence to another hotel in Craigmyle and could not grant another. ${ }^{147}$ The Board's denial of the policy's existence was possible because it was never explicitly codified, nor made public by the Board. The reason the Board denied its existence to Cameron was likely due to Cameron's reputation as a man unafraid to challenge the liquor laws. He had been a regular opponent of the prohibition era liquor laws and had successfully defended many Chinese Canadians charged with The Liquor Act violations. ${ }^{148}$ As it happens, Cameron accepted the Board's second explanation and the Board's anti-Chinese policy went unchallenged.

Although licencing decisions offered one way to assess the Board's impartiality and independence, there were other factors which influenced how licensees viewed the Board. During its early years the ALCB was quite strict with hotel licensees and its hotel inspectors often suggested a number of improvements with each inspection. The ALCB also responded swiftly to any complaints of drunkenness or misbehaviour in licenced hotels. Doubtless many complaints had some basis, but many did not and the AHA's members grew increasingly frustrated with the ALCB. In 1930 Charles Traunweiser, the AHA President, wrote a lengthy letter to Chairman Dinning outlining hotel licensees' complaints. "The opinion prevails," wrote Traunweiser, "that, perhaps, you and your Government pay too much attention to petty complaints." Furthermore Traunweiser said that hotel owners felt like "the most persecuted people in the entire Province," and that the ALCB Inspectors made recommendations that

Letter from Dinning to Messrs Lawlor \& Sisson, Barristers (26 August 1930), Edmonton, Provincial Archives of Alberta (RG 74.412, file 1307).

146 Such feeling was not limited to Alberta and was common across Canada during the inter-war period: see Constance Backhouse, "The White Women's Labor Laws: Anti-Chinese Racism in Early TwentiethCentury Canada" (1996) 14:2 L \& Hist Rev 315; Nancy M Forestell, "Bachelors, Boarding-Houses, and Blind Pigs: Gender Construction in a Multi-Ethnic Mining Camp, 1909-1920" in Franca Iacovetta, Paula Draper \& Robert Ventresca, eds, A Nation of Immigrants: Women, Workers, and Communities in Canadian History, 1840s-1960s (Toronto: University of Toronto Press, 1998) 251; Constance B Backhouse, "White Female Help and Chinese-Canadian Employees: Race, Class, Gender and Law in the Case of Yee Clun, 1924" (1994) 26:3 Can Ethnic Studies 34.

147 Letter from FG Forster, Supervisor of Licenses to J McKinley Cameron (30 April 1924); Letter from McKinley Cameron to the Alberta Liquor Control Board (11 July 1924); Letter from McKinley Cameron to Lai Noon (17 July 1924), Calgary, Glenbow Alberta Institute Archives (RG M-6840, file 390).

Many of Cameron's files are now housed in the Glenbow Alberta Institute Archives and include many of his prohibition-era cases. The J McKinley Cameron fonds, Glenbow Alberta Institute Archives (RG M-6840). Cameron's most famous client was the notorious bootlegger Emilio Picariello. For a brief overview of Cameron's career: see James H Gray, Talk to My Lawyer! Great Stories of Southern Alberta's Bar \& Bench (Edmonton: Hurtig, 1987) at 59. 
were either unreasonable or petty such as criticizing hotel owners for having dust above a door frame. ${ }^{149}$

Traunweiser wrote his letter during a difficult time for Alberta's licenced hotels. The Depression had placed further pressure on Alberta's fragile economy which was still reeling from the agricultural crisis of the early 1920s. ${ }^{150}$ Not surprisingly, the Prohibitionists were trying to use the economic crisis to justify liquor reforms, particularly the closure of the beer parlours. As a result of Prohibitionist agitation, the ALCB banned individuals on relief from buying alcohol or drinking in the beer parlours. ${ }^{151}$ Given that most hotels only managed to stay in business because of what little profit they made from their beer parlours, licensees were understandably anxious about anti-beer parlour feeling. Licensees were also frustrated with the ALCB's response to Prohibitionist agitation. Traunweiser's letter suggests that the AHA wanted the ALCB to do more to defend licenced hotels against the accusations of the Prohibitionists instead of pandering to them. The ALCB's annual report from 1930 could be read as a tacit defence of the hotels but the Board seemed unwilling to explicitly state that the Prohibitionists' complaints were often a waste of time.

Traunweiser's accusations with respect to constant improvements are also a little unfair. The Board did not always insist on the repairs and recommendations suggested by their hotel inspectors. Certain major repairs, such as new heating plants, as well as certain repairs which were beyond the licensees' sole control, such as poor toilet facilities due to the lack of indoor plumbing in the region, appear year after year in a hotel's licence file. ${ }^{152}$ Inspectors may have been able to nitpick more effectively in the cities where the threat of another hotel being licenced instead offered a good incentive to implement the recommendations, but this did not hold true province-wide. In other words, the ALCB was not being as strict as it claimed to be in its annual reports, nor as unfair as many licensees may have perceived it to be.

Nonetheless, hotel licensees lacked the political clout that the Prohibitionists seemed to have. That said, by 1930 the government and Premier Brownlee appeared to be paying little more than lip service to the Prohibitionists' demands and, in fact, consistently refused to take any firm action. ${ }^{153}$ Even though the UFA government maintained that it supported prohibition, in a practical sense government liquor sales were essential. Not only did liquor sales provide much needed revenue, the majority of Albertans were in favour of them, and there was a consensus that the Liquor Control Act was better than The Liquor Act.

Letter from Chas Traunweiser to RH Dinning, (5 May 1930), Edmonton, Provincial Archives of Alberta (RG 69.289, file 99a).

For discussion of this crisis: see Jones, supra note 73; EJ Hanson, "Public Finance in Alberta Since 1935" (1952) 18:3 Can J Economics \& Political Science 322 at 322.

"Vendor's and Beer Halls Closed to Unemployed Here," Calgary Herald (15 November 1930) 17. The ALCB took to including the relief lists when they sent the beer licence to licensees: see e.g. Letter from the Chairman of the Alberta Liquor Control Board to Messrs Fairview Hotel Company Limited (22 December 1932), Edmonton, Provincial Archives of Alberta (RG 74.412, file 1308).

See e.g. the Reports noting that the Dominion Hotel at Spirit River needed a new heating plant, Report of Inspector (19 May 1938), Edmonton, Provincial Archives of Alberta (RG 74.412, file 2388); Report of Inspector on Hotel Application (23 November 1939), Edmonton, Provincial Archives of Alberta (RG 74.412, file 2388); Report of Inspector on Hotel Application (5-6 September 1940), Edmonton, Provincial Archives of Alberta (RG 74.412, file 2388); This hotel also had issues with running water. Hamill, "Prohibition Plebiscites," supra note 87 at 402-409. 
The Prohibitionists did not pick up on what the government's lack of concrete action meant and it would seem as though the ALCB failed in this regard as well. The ALCB seemed to attribute its success to its ability to strictly enforce the Liquor Control Act rather than to the desire of the majority of Albertans to access liquor. ${ }^{154}$ Such a belief was likely longstanding as in 1924, Emily Murphy, Canada's first female magistrate and former temperance activist, had praised Alberta's new Liquor Control Act for its strictness. In an interview with the Ottawa Journal, Murphy said that the new Act was rigorously enforced and that the Act's "ruthless penalties" really worked. ${ }^{155}$

At times, particularly during its early years, the ALCB did not seem confident in its own survival and this affected its independence. Under Dinning, who remained Chairman until $1937,{ }^{156}$ the ALCB appeared cautious and sought the approval of government for a number of things including regulations and locations of liquor stores. The ALCB was also keenly aware of public opinion and erred on the side of listening to the Prohibitionists' complaints over the suggestions or wishes of other interested parties. Of course, the Prohibitionists' complaints often had substantial overlap with the government's wishes and this usually worked to keep the enforcement of the Liquor Control Act as strict as possible. In responding to the Prohibitionists the ALCB may also have worked to prevent their criticisms from spreading. The government's occasional hints during the ALCB's early years that liquor sales were an experiment and may only be temporary warned the Board that it had to prove itself, which for the government meant that it had to control liquor better than prohibition had done. $^{157}$

Yet public opinion could also work to protect the ALCB from excessive government meddling as illustrated by Dinning's departure from the Board. Dinning resigned two years after the UFA were swept from office by the Social Credit party (SoCreds). ${ }^{158}$ Dinning had worked closely with the UFA government but rather than replace him, the new government reduced his salary in 1936 and he resigned the following year. ${ }^{159}$ Dinning's salary cut was part of a broader cut to the salaries of high-ranking civil servants and was prompted by ongoing financial difficulties. ${ }^{160}$ While it is unclear whether the SoCreds wanted Dinning to resign, the power to reduce salaries could push a Board member out and avoid the need to publicly fire that member. Regardless of what prompted Dinning's resignation or the SoCreds' decision to cut salaries, some Albertan newspapers viewed Dinning's resignation

See e.g. Sessional Papers No 3, supra note 135 at 5-8.

Sir John Willison, "Alberta Liquor Act: One Woman's View," Ottawa Journal (undated clipping c. 1924), Edmonton, Provincial Archives of Alberta (RG 69.289, file 98a). This article is also cited in Scott Thompson \& Gary Genosko, Punched Drunk: Alcohol, Surveillance and the LCBO 1927-1975 (Black Point, NS: Fernwood, 2009) at 87.

"Dinning Resigns," Lethbridge Herald (12 February 1937) 1 ["Dinning Resigns"]. He was replaced by JA King: see "No Radical Changes in Operation Liquor Act Contemplated," Lethbridge Herald (26 October 1937) 7.

Letter from Premier to HT Sullivan, General Secretary of the Civil Service Association (20 April 1926), Edmonton, Provincial Archives of Alberta (RG 69.289, file 130a); "New Liquor Control Law," supra note 128 at 1.

For their election victory, see Alvin Finkel, "1935: The Social Credit Revolution" in Payne, Wetherell \& Cavanaugh, supra note 73,490 at 491 .

Dinning was paid $\$ 9000$ in 1933 but the government cut this by $\$ 1,560$ in 1936: see "Beer Permit Cancellation Is Protested," Lethbridge Herald (22 March 1933) 1; "Salaries of Higher-Ups are Slashed," Lethbridge Herald (2 March 1936) 1; "Dinning Resigns," supra note 156.

"A Salary Grab," Bassano Recorder (1 July 1937) 2. 
as further evidence of the decline of government under the SoCreds. ${ }^{161}$ The media response to Dinning's resignation suggests, however, that overt government interference with the ALCB would have been unpopular and this unpopularity may have worked to protect the Board. At the same time, the apparent respect the media had for Dinning suggests that he, and by extension the ALCB, had managed to please public opinion.

As a statutory delegate, the Board's existence remained dependent on the government. In turn, the government was itself dependent on winning electoral victories. Consequently, it is not surprising that the ALCB took care to please both the government and the Prohibitionists as far as possible, as the latter group appeared to have a disproportionate influence over the government. Though such care on the part of the ALCB was not strictly required under the Liquor Control Act, it was needed on a practical level. As such, the ALCB's ability to act independently was limited in ways which were not always immediately obvious to observers and this complicated the Board's administrative independence.

\section{THE ALCB'S RELATIONAL INDEPENDENCE: SOME BROADER IMPLICATIONS}

Writing in the late 1970s, Janisch noted the importance of "structural independence" when it came to regulatory agencies. ${ }^{162}$ What he meant was that how such agencies were set up and defined, as well as "the very broad terms of [their] mandates" helped push them away from the direct control of government. ${ }^{163}$ This relatively brief overview of the ALCB suggests that in some ways Janisch's observations are correct. Simply by creating a separate liquor board, the provincial government did seem to commit to not interfering in the Board's decisionmaking process, or at least not overtly interfering. Yet, at the same time, the uncertainty over both the ALCB's own survival and the province's financial situation may have pushed the ALCB to seek more government approval than was imagined by the Liquor Control Act. This section explores some of the broader implications of the ALCB's relationship with government for administrative independence as a whole.

This brief discussion of the ALCB and its relationship with the government is, in some ways, reassuring. It shows that administrative agencies can and do develop their own policies which they apply in accordance with the rule of law. In the case of the ALCB, its licencing decisions were, as a general rule, based on the hotel building and not the licensee (provided, of course, that the licensee was of good character). ${ }^{164}$ The exception here was the Board's anti-Chinese policy, a policy which reflected the anti-Chinese feeling of many Albertans. As noted, the Board did make one exception to this racist policy but it only did so because Charlie Wing had the support of the local community. Even though Wing ran a good hotel, the Board did not grant him another licence in a neighbouring village due to the opposition of that village to a Chinese Canadian being licenced. The Board did not seek to defend Wing, it merely followed public opinion.

"Mr Dinning Resigns," Lethbridge Herald (13 February 1937) 4; "The Coming Session," Bassano Recorder (18 February 1937) 2.

Janisch, "Policy Making," supra note 6 at 56.

Ibid.

Liquor Control Act, supra note 1, s 33(d). 
The ALCB also adopted a strictly non-partisan policy for its staff members. Prior to the 1926 provincial general election, Chairman Dinning sent a circular to all staff reminding them that "[i]t is of the utmost importance that the administration and operation of the liquor Act be kept absolutely free from politics." ${ }^{\prime 65}$ In other words, staff members were not to discuss politics at work. Dinning's caution here is relatively standard for agencies that are funded by the government, as it is inappropriate for the governing party to use public funds to promote itself. ${ }^{166}$

The awkward political, constitutional, and legal status of boards like the ALCB might actually encourage such boards to act impartially and in accordance with the rule of law. The ALCB was keenly aware of the public's opinion, its own precarious status (the Board could have been abolished at any time); and the relationship between public approval and its own survival. Modern administrative agencies remain as vulnerable to abolition as the ALCB was, ${ }^{167}$ they are closer to the public than the government is, and they are also subject to many forms of accountability. The ALCB was, for example, accountable to the government, the public, the legislature, and, theoretically, the courts as well. These multiple layers of accountability could work, and did work in the case of the ALCB, to encourage administrative agencies to stick closely to their mandate and to develop procedures to address concerns about political partiality.

It is not clear, however, that the ALCB was as responsive to public opinion as it strove to be. The ALCB's decision to err on the side of strictness was one supported by the staunchly Prohibitionist UFA government, not necessarily the majority of the public. The Prohibitionists were vocal but they were in the minority. The ALCB's strictness is arguably an example of the squeaky wheel getting the oil. Yet the Prohibitionists may not have succeeded in being heard had their views not been amplified by the government's support of them. The government did not, however, force the ALCB to be strict; it just strongly implied that strictness was appropriate. Consequently, political influence over administrative agencies can be indirect as well as direct. In Roncarelli, for example, the liquor Board could have revoked Roncarelli's licence on its own initiative instead of following Duplessis' orders. As such, the ALCB arguably made some decisions based on what would be best for its own survival rather than what was the best way to regulate liquor sales. If administrative independence were held to the same standards as judicial independence, even the appearance of bias would be enough to violate the ALCB's independence. However, administrative independence, even in the context of adjudication, is not held to the same standards as judicial independence and so some bias may well be present, if not expected. The ALCB was, after all, enforcing a government policy of strict control on liquor.

Though there were some uncertainties hanging over the ALCB during its early years, its relationship with the government seemed largely positive. The government did not actively work to undermine the Board, nor did its hotel licensees, or the broader public. The reformed in 1996 to become the Alberta Liquor and Gaming Commission (Gaming and Liquor Act, SA 1996, c G-0.5, s 2). 
government could have intervened in the ALCB's role in licensing hotels, but chose not to. Such a hands-off approach, coupled with both public and industry support, was not the case for many other early boards. Alberta's first attempt at an oil and gas regulatory body, for example, failed in the face of both industry and judicial opposition. ${ }^{168}$ Similarly, other early administrative agencies such as the Board of Railway Commissioners, failed due to the hostility of those they were supposed to regulate. ${ }^{169}$ This complicates the picture of administrative independence and shows how administrative agencies are vulnerable to public opinion and the support of those they regulate. ${ }^{170}$

By paying attention to the ALCB's relationship with the government, it is clear that the ALCB was, in some ways, dependent on the government. Public opinion may have acted to grant at least some security of tenure to Dinning as Chairman and sole Board member, but the government had other ways to push Dinning out, such as reducing his salary. ${ }^{171}$ Security of tenure, like the other factors that administrative law scholars have identified as being essential for administrative independence, is relational in the sense that it speaks to the relationship between the administrative body and executive government. ${ }^{172}$ The exact shape that this relationship took for the ALCB was structured in part by the Liquor Control Act and in part by the personalities and practicalities of governing Alberta in the 1920s. It might have been better, for example, had the Board had its own solicitor, yet that would have cost more. The government's decision to limit the ALCB to one Board member could have been motivated by a desire to keep the Board under control or simply by a desire to limit expenditures on salaries and so on.

Dinning's pay cut and subsequent resignation point to the relative weakness of the court of public opinion. Certainly, the SoCred government faced criticism over Dinning's resignation but the criticism was short-lived. Sossin identified a similar phenomenon more recently with his examination of public "allegations ... of political interference with ... Elections Canada, the Military Complaints Commission and the Canadian Nuclear Safety Commission" and noted that the allegations generated a brief flurry of negative press before disappearing. ${ }^{173}$ Had Dinning been fired by the government, he would have had no recourse given that his appointment was at-pleasure. Even today Dinning would likely have had no recourse, as following the logic of the Supreme Court in Dunsmuir v. New Brunswick, the dismissal of pleasure appointees should be considered a contractual, not public law issue. ${ }^{174}$ Similarly, Dinning had no remedy for the cut in his salary. His pay cut was part of a broader pay cut and such widespread pay cuts are, or so the Quebec Court of Appeal recently held, compatible even with adjudicative independence. ${ }^{175}$ In CLP, the Court of Appeal noted that the pay cut was a response to a crisis in public finances, and that freezing or reducing pay

See David H Breen, Alberta's Petroleum Industry and the Conservation Board (Edmonton: University of Alberta Press, 1993) at 79-94 (discussing the fate of the Turner Valley Gas Conservation Board).

See Benidickson, supra note 5; Hibbitts, "Bridle for Leviathan," supra note 5.

Compare Ellis's description of the WCAT prior to the 1995 election of the Progressive Conservative government in Ontario, noting that no tribunal chair would be appointed unless the Deputy Minister of Labour believed the candidate had the support of the unions and employers: Ellis, Unjust by Design, supra note 4 at 10 .

For a discussion of Dinning's resignation, see the text accompanying notes 157-60.

Jacobs, supra note 4 at 298.

Sossin, "Puzzle," supra note 6 at $3,15,22$.

2008 SCC 9, [2008] 1 SCR 190 at paras 79-82, 115.

CLP, supra note 27 at para 105 . Nonetheless, the CLP succeeded here because they had a statutory guarantee with respect to their remuneration (ibid at paras 128-34). 
is not enough to threaten the financial security of tribunal members. ${ }^{176}$ However, this does place administrators like Dinning at the mercy of the government.

Security of tenure is perhaps an awkward fit for boards like the ALCB given their close connection with government policy and the related need to easily get rid of underperforming administrators. Nonetheless, there are those who argue that "“at pleasure' appointments are inherently inappropriate to adjudicative, oversight and accountability positions" 177 and this argument does seem intuitively correct. Unfortunately, the Canadian administrative state is not yet structured in a way that can recognize and enforce such arguments. ${ }^{178}$ There may be something of a political convention which could protect individuals appointed to "adjudicative, oversight and accountability positions," 179 in that where a government makes a commitment to creating an independent body, the legislature will hold them to it. In the context of the ALCB the government said that it was an independent body, but the wording of the Liquor Control Act granted the government the power to add or remove members and set their salaries, suggesting that the ALCB was not as independent as it could have been. Even if there is a political convention of administrative independence with respect to certain bodies, conventions are not enforced by the courts. Absent statutory guarantees, or quasiconstitutional protections, the relationship between the government and an administrative agency is as independent or as dependent as the government wants it to be.

Yet the relationship between an administrative body and the executive is itself one of many permeating government and the administrative state. The ALCB's experiences highlight how challenging it can be for a new board to manoeuvre the various competing relationships, and it is this aspect of administrative independence which is hard to grasp. Administrative bodies must be responsive to public demand and government policy, while making their decisions according to the rule of law. Much like the range of functions which an administrative body performs, the pressures on such bodies pull them in different directions. It is not clear that policies or procedures could be put in place which would help boards navigate these competing pressures and balance the demands of the various relationships that boards find themselves in. In the case of the ALCB, the Board was seen as too strict by hotel licensees yet could never be strict enough to satisfy the Prohibitionists. As such the ALCB seemed to constantly adapt its strategy, and oscillated between being demanding of licensees and tacitly defending them. Similar oscillations might also be seen in modern boards which regulate complex and controversial areas, though without further study it will be impossible to know.

\section{CONCLUSION}

Administrative independence is perhaps as much a political statement as it is a reflection of the actual relationships that administrative agencies have with executive government. There are structural reasons why boards and tribunals can and do act independently of government. There are also justice-related reasons why some boards are afforded more

178 Quebec offers a potential exception: see France Houle, "Constructing the Fourth Branch of Government for Administrative Tribunals" (2007) 37 SCLR (2d) 117. 
independence than others, particularly in the context of bodies with a mainly adjudicative function. There are also other reasons, usually related to accountability, to explain why such bodies are not entirely independent from any branch of government, whether executive, legislative, or judicial. In addition to these more abstract reasons, there are also the practical realities of administrative government to take into account, which may explain why executive government takes a keener interest in some boards and not others. In the case of the ALCB, Alberta's government was deeply interested in the Board's profits but also in denying that it was interested in those profits.

This study of the ALCB has also shown that administrative independence can cut both ways. Not only can it act as a justification for administrative government, but it can work to protect the executive from association with controversial decisions. The dual aspect of administrative independence speaks to a certain political culture, one which is broadly suspicious of government intervention, while highlighting that the balance inherent in the idea of the separation of powers is one which is dependent on the relationships that exist between the branches of government and between the government and the public. 